\title{
Study of Physicochemical Properties of Commercial Drinking Bottled Water Brands
}

\author{
Abdul Rehman Jatoi \\ Department of Energy and Environment \\ Engineering, Quaid-e-Awam University \\ of Engineering, Science and Technology, \\ Nawabshah, Sindh, Pakistan \\ arjatoi@quest.edu.pk
}

\author{
Abdul Qayoom Jakhrani \\ Department of Energy and Environment \\ Engineering, Quaid-e-Awam University \\ of Engineering, Science and Technology, \\ Nawabshah, Sindh, Pakistan \\ aqunimas@ hotmail.com
}

\author{
Kishan Chand Mukwana \\ Department of Energy and Environment \\ Engineering, Quaid-e-Awam University \\ of Engineering, Science and Technology, \\ Nawabshah, Sindh, Pakistan \\ kcmukwana@quest.edu.pk
}

\author{
Abdul Nasir Laghari \\ Department of Energy and Environment Engineering, Quaid-e- \\ Awam University of Engineering, Science and Technology, \\ Nawabshah, Sindh, Pakistan \\ mashaalnasirlaghari@gmail.com
}

\author{
Muhammad Mureed Tunio \\ Department of Energy and Environment Engineering, Quaid-e- \\ Awam University of Engineering, Science and Technology, \\ Nawabshah, Sindh, Pakistan \\ mureed.tunio@gmail.com
}

\begin{abstract}
Drinking water quality is being affected by industrial effluents, pesticides and fertilizers, poor sanitation services and unhygienic practices. Thus, upper and middle-class people used to prefer bottled water for drinking instead of tap water. Increasing demand for bottled water leads to the presence of low quality branded waters in the market due to the high demand and improper quality checks. In this regard, this study is carried out to assess the physicochemical properties of various branded bottled waters. For that, ten different water brand samples, coded from S1 to S10, were collected from Safoora Goth, Karachi. Various physicochemical quality parameters of branded water samples were analyzed according to the set procedures of American Society for Testing and Materials. It was discovered that the $\mathrm{pH}$ levels of S9 and S8 bottled water brands were slightly less than World Health Organization guideline values. The physical and chemical quality parameters of S1, S2, S4, S5, S7, and $\mathrm{S} 10$ branded bottled water samples were found within standards.
\end{abstract}

Keywords-drinking water; bottled water; physicochemical properties; contamination

\section{INTRODUCTION}

Sufficient quantity of clean and safe water is crucial to human health [1-3]. Population growth, rapid urbanization, industrialization, changing lifestyles and economic development cause severe stress not only on the quantity of available water resources but also on its quality $[4,5]$. Water resources are being contaminated by different physical, chemical and biological agents. Its quality control is essential for environment preservation and for public health protection [6]. Increasing rate of pollution in fresh water resources amplified the demand for bottled water [7]. Bottled water consumption has significantly increased the last three decades, particularly in food and beverage industries with an annual average of $12 \%$ in spite of its high cost [8]. Its annual average consumption is more than 100 liters per person in fifteen countries, and over 200 liters per person in Mexico, Italy, and the United Arab Emirates [7].

It is reported that bottle water utilization has been increased enormously in Pakistan, approximately from $6 \%$ to $10 \%$ from 2003 to 2007 [9-12]. Karachi is the biggest urban center and city of Pakistan having population of more than 16 million [13, 14]. Upper and middle class people use to prefer bottled water for drinking purpose instead of using tap water as it is considered to be free from contaminants $[1,11,12,15,16]$. Although it is prerequisite for bottled water brands to register for quality production in Pakistan, nevertheless replicas and inferior brands are posing serious threat to the public health. Its high demand leads to the existence of low quality brands in the market [17]. The present study is an attempt to investigate on the physicochemical quality parameters of different branded bottled waters, commonly consumed by the people of Karachi.

\section{MATERIALS AND METHODS}

Samples from ten local bottled water brands were taken from different shops and supermarkets of Safoora Goth during the September to October time period. Five samples of each brand were examined in the laboratory. The sample brands were assigned codes from S1 to S10. These codes were assigned for recognition of water samples during and after analysis. Thermo-set containers were used to preserve the samples at $25^{\circ} \mathrm{C}$ [18-20]. The drinking quality parameters examined in the laboratory were $\mathrm{pH}$, TDS, EC, salinity, alkalinity, chlorides, hardness, turbidity, color, nitrates and fluorides. PH meter, gravimetric method, floating glass hydrometer and HI98302 meter were used to analyze $\mathrm{pH}$, TDS, salinity and EC respectively. Titration method was employed for alkalinity, total hardness and chloride measurements. Turbidity was measured with the use of a nephelometer 
(turbidimeter), color by Platinum-Cobalt method and nitrates with phenol disulphuric acid method. Fluoride content in was tested with spectrometer.

\section{RESULTS AND DISCUSSION}

All samples were examined according to defined procedures of ASTM and were compared with WHO standards.

\section{A. Turbidity, Colour and $\mathrm{pH}$}

Turbidity level and color of all examined samples were found within permissible limits. The level of $\mathrm{pH}$ in examined water samples is shown in Figure 1. Maximum $\mathrm{pH}$ value of 8.21 was found in $\mathrm{S} 3$ and minimum in $\mathrm{S} 9$ with 6.1 .

\section{B. TDS and EC}

The values of total dissolved solids (TDS) samples are given in Figure 2. Maximum TDS of $383 \mathrm{mg} / \mathrm{l}$ was found in S9 and minimum $156 \mathrm{mg} / 1$ in $\mathrm{S} 1$ and $\mathrm{S} 2$. Besides TDS, the results of electrical conductivity (EC) are given in Figure 3. The maximum electrical conductivity value was found in S5 with $490 \mu \mathrm{S} / \mathrm{cm}$ and minimum from S1 with $333 \mu \mathrm{S} / \mathrm{cm}$. The EC of all samples was found within WHO allowable limit of $2500 \mu \mathrm{S} / \mathrm{cm}$.

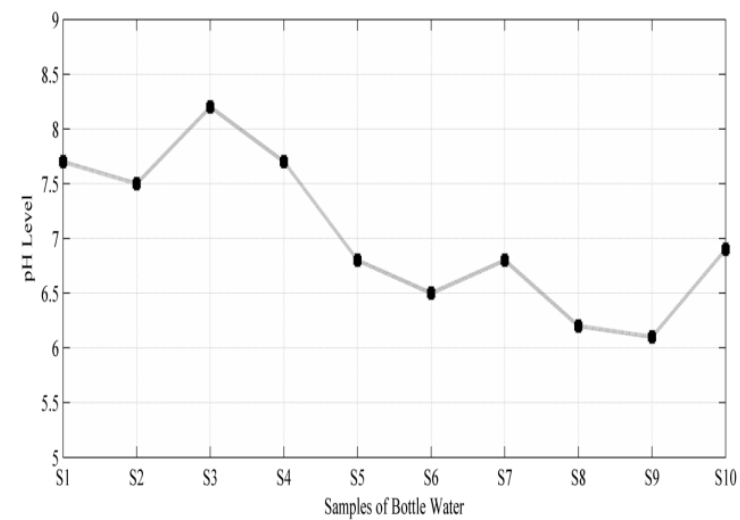

Fig. 1 Level of $\mathrm{pH}$ in local brand bottled water samples

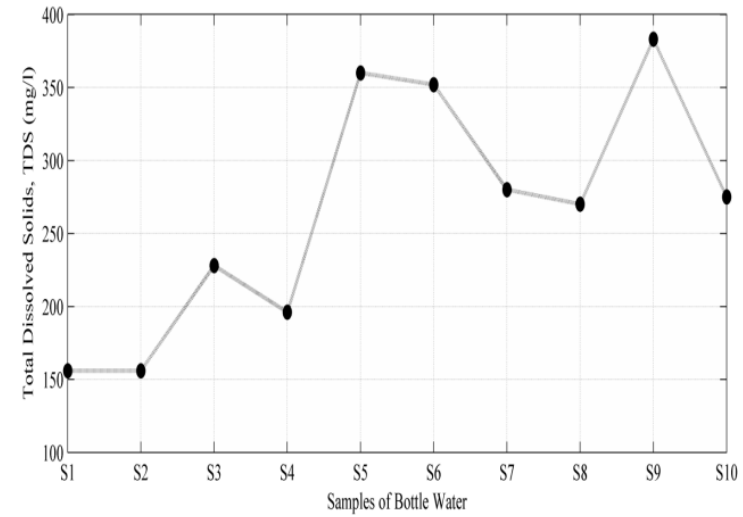

Fig. 2 Level of total dissolved solids in local brand bottled water samples

\section{Salinity, Alkalinity and Hardness}

Figure 4 displays the analyzed values of salinity. Three brands, namely S5, S6 and S7 displayed maximum salinity of
$0.3 \%$. The minimum concentrations of salinity were found in $\mathrm{S} 1, \mathrm{~S} 2, \mathrm{~S} 3, \mathrm{~S} 4, \mathrm{~S} 8, \mathrm{~S} 9$ and $\mathrm{S} 10$ with $0.2 \%$. Moreover, maximum alkalinity of $120 \mathrm{mg} / \mathrm{l}$ was found in $\mathrm{S} 2$ and minimum $53 \mathrm{mg} / 1$ in $\mathrm{S} 8$ as shown in Figure 5. Similarly, the maximum level of hardness with $103 \mathrm{mg} / \mathrm{l}$ was found in $\mathrm{S} 8$ and minimum $33.25 \mathrm{mg} / 1$ in $\mathrm{S} 1$ as shown in Figure 6. The results of hardness in all water samples were within WHO guideline value of $<500 \mathrm{mg} / 1$.

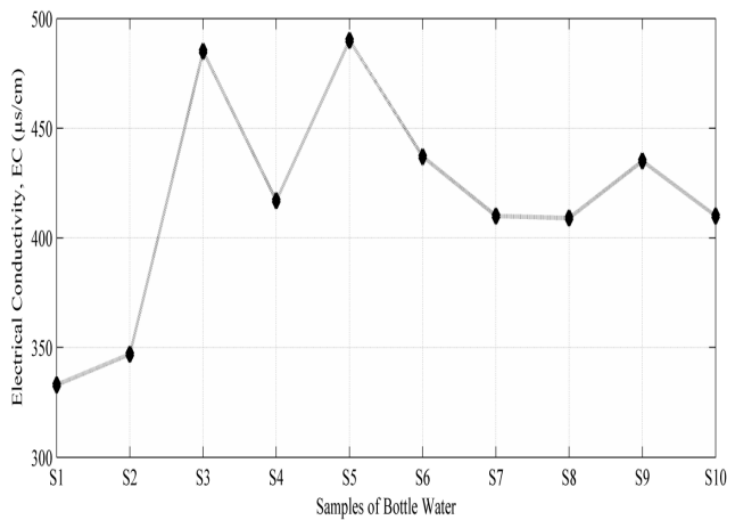

Fig. 3 Level of electrical conductivity in local brand samples

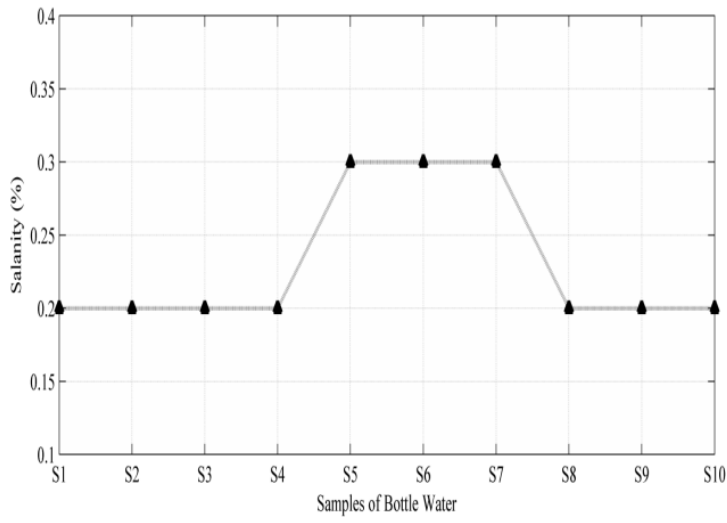

Fig. 4 Level of salinity in local brand bottled water samples

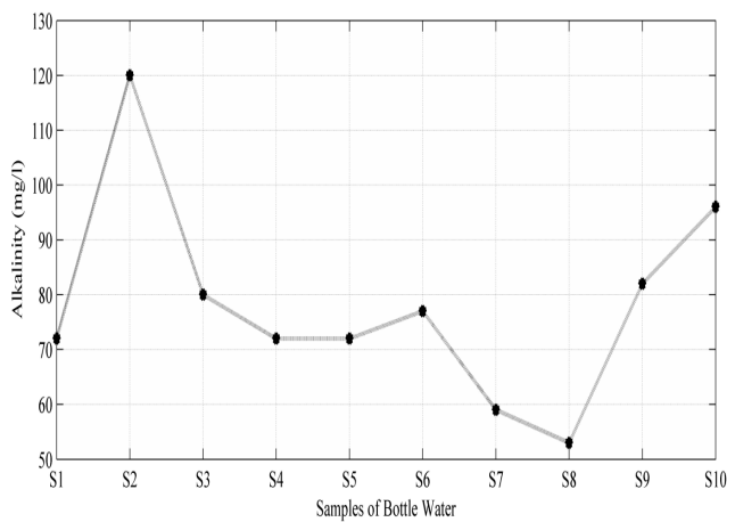

Fig. 5 Level of alkalinity in local brand bottled water samples

\section{Chloride, Fluoride and Nitrates}

The Chloride results are displayed in Figure 7. Maximum chloride value of $130 \mathrm{mg} / \mathrm{l}$ was found in S5 and minimum of 
$42.54 \mathrm{mg} / 1$ in $\mathrm{S} 1$. The level of fluoride in water samples is shown in Figure 8. Maximum fluoride value was $0.9 \mathrm{mg} / \mathrm{l}$ in $\mathrm{S} 3$ and minimum in S1, S7 and S8 brands with $0.2 \mathrm{mg} / \mathrm{l}$. Figure 9 demonstrates the values of nitrates in the samples. Maximum of $21 \mathrm{mg} / 1$ was found in $\mathrm{S} 6$ and minimum $0.6 \mathrm{mg} / \mathrm{l}$ in $\mathrm{S} 1$.

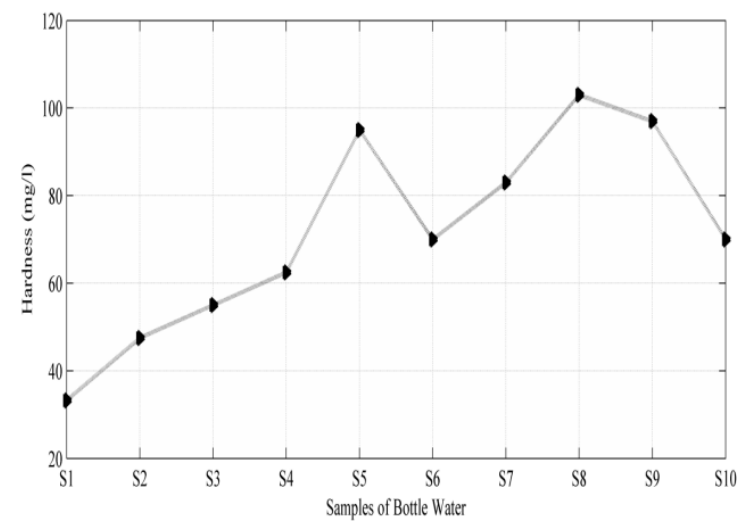

Fig. 6 Level of hardness in local brand bottled water samples

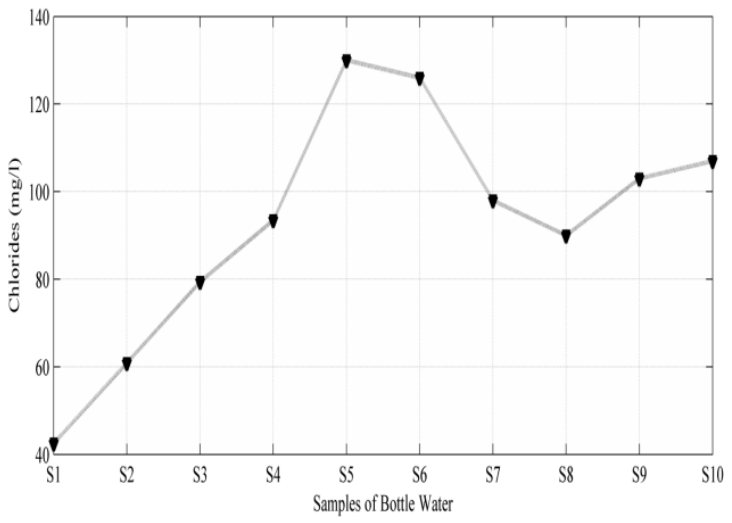

Fig. 7 Level of chlorides in local brand bottled water samples

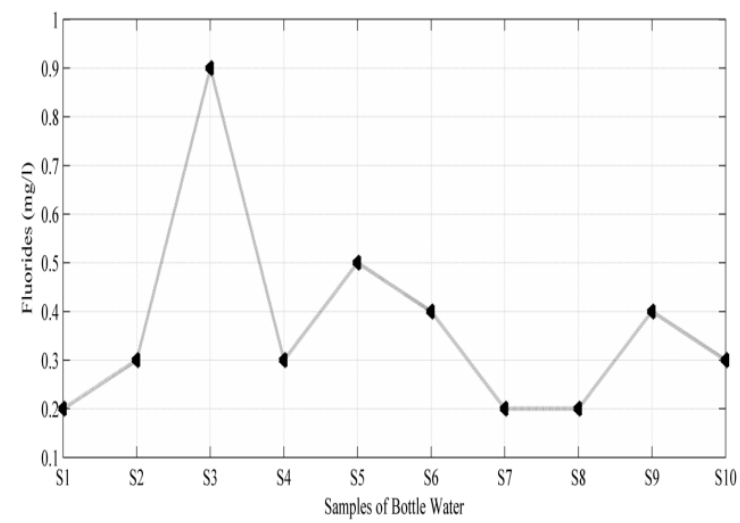

Fig. 8 Level of fluoride in bottled water samples

\section{CONCLUSION}

In this study, water samples of bottled water from 10 local brands were assessed for physicochemical properties. It was found that the $\mathrm{pH}$ value of $\mathrm{S} 9$ and $\mathrm{S} 8$ bottled water samples were slightly less than WHO guideline values. The results of $\mathrm{S} 1, \mathrm{~S} 2, \mathrm{~S} 4, \mathrm{~S} 5, \mathrm{~S} 7$ and S10 water brands were found within guideline values. It is strongly recommended that environmental protection agencies organize seminars, workshops and training programs to create awareness about the adverse impacts of polluted water.

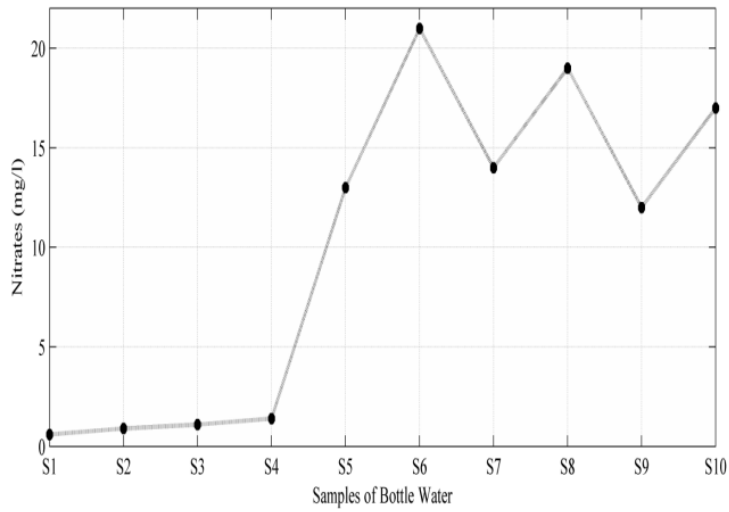

Fig. 9 Level of nitrates in local brand bottled water samples

\section{REFERENCES}

[1] A. Khatoon, Z. A. Pirzada, "Bacteriological quality of bottled water brands in Karachi, Pakistan", Biologia (Pakistan), Vol. 56, No. 1-2, pp. 137-143, 2010

[2] O. Oyedeji, P. O. Olutiola, M. A. Moninuola, "Microbiological quality of packaged drinking water brands marketed in Ibadan metropolis and Ile-Ife city in South Western Nigeria", African Journal of Microbiology Research, Vol. 4, No. 1, pp. 96-102, 2010

[3] Z. Peh, A. Sorsa, J. Halamic, "Composition and variation of major and trace elements in Croatian bottled waters", Journal of Geochemical Exploration, Vol. 107, No. 3, pp. 227-237, 2010

[4] E. O. Oyelude, S. Ahenkorah, "Quality of sachet water and bottled water in Bolgatanga municipality of Ghana", Research Journal of Applied Sciences, Engineering and Technology, Vol. 4, No. 9, pp. 1094-1098, 2012

[5] R. Cidu, F. Frau, P. Tore, "Drinking water quality: Comparing inorganic components in bottled water and Italian tap water", Journal of Food Composition and Analysis, Vol. 24, No. 2, pp. 184-193, 2011

[6] S. N. Majid, Z. H. G. Ahmad, Z. K. Muhammad, "A study of some physicochemical parameters of plastic bottled drinking water from different sources (manufactured brands) in Kurdistan Region-Iraq", International Journal of Plant, Animal and Environmental Sciences, Vol. 5, No. 4, pp. 129-133, 2015

[7] M. Diduch, Z. Polkowska, J. Namiesnik, "Factors affecting the quality of bottled water", Journal of Exposure Science and Environmental Epidemiology, Vol. 23, No. 2, pp. 111-119, 2013

[8] E. I. Brima, "Physicochemical properties and the concentration of anions, major and trace elements in groundwater, treated drinking water and bottled drinking water in Najran area, KSA", Applied Water Science, Vol. 7, No. 1, pp. 401-410, 2017

[9] J. J. Toma, N. S. Hanna, B. A. Mohammed, "Effect of storage condition on some bottled water quality in Erbil city, Kurdistan region-Iraq", International Journal of Software and Web Sciences, Vol. 3, No. 1, pp. $33-43,2013$

[10] L. W. Mays, Water Resources Engineering, John Wiley \& Sons, 2010

[11] W.H.O., Guidelines for Drinking Water Quality, WHO, Geneva, Switzerland, 2004

[12] M. T. Samadi, A. R. Rahmani, M. Sedehi, N. Sonboli, "Evaluation of chemical quality in 17 brands of Iranian bottled drinking waters", Journal of Research in Health Sciences, Vol. 9, No. 2, pp. 25-31, 2009

[13] F. Perveen, U. Asghar, T. H. Usmani, "Evaluation of Water Quality of Different Colleges of Karachi City", Journal of the Chemical Society of Pakistan, Vol. 29, No. 5, pp. 458-462, 2007 
[14] S. T. Betelhem, Development Impacts of Poor Accessibility of Potable Water Supply and Basic Sanitation in Rural Ethiopia: A case study of Soddo District, MSc Thesis, University of Agder, 2011

[15] S. D. Raj, "Bottled water: how safe is it?", Water Environment Research, Vol. 77, No. 7, pp. 3013-3018, 2005

[16] I. Z. Mihayo, S. L. Mkoma, "Chemical Water Quality of Bottled drinking water brands marketed in Mwanza city, Tanzania", Research Journal of Chemical Sciences, Vol. 2, No. 7, pp. 21-26, 2012

[17] N. Rosemann, Drinking Water Crisis in Pakistan and the Issue of Bottled Water: The Case of Nestlé's 'Pure Life, Actionaid Pakistan, 2005

[18] S. R. Samo, A. R. Jatoi, F. H. Mangi, A. N. Laghari, K. C. Mukwana, "Design of a slow sand bed filtration system for purification of canal water", Quaid-e-Awam University Research Journal of Engineering, Science \& Technology, Vol. 14, No. 1, pp. 14-18, 2015

[19] K. H. Lashari, A. L. Korai, G. A. Sahato, T. G. Kazi, "Limnological studies of Keenjhar lake, district, Thatta, Sindh, Pakistan", Pakistan Journal of Analytical and Environmental Chemistry, Vol. 10, No. 1-2, pp. 39-47, 2009

[20] M. F. Alam, N. C. Dafader, S. Sultana, N. Rahman, T. Taheri, "PhysicoChemical Analysis of the Bottled Drinking Water available in the Dhaka City of Bangladesh", Journal of Materials and Environmental Science, Vol. 8, No. 6, pp. 2076-2083, 2017 